\title{
Dietary protein and energy requirements of juvenile freshwater angelfish
}

\section{Jener Alexandre Sampaio Zuanon ${ }^{1}$, Ana Lúcia Salaroํㅜ, Sofia Simões Silveira Moraes ${ }^{2}$, Leandro Moreno de Oliveira Alves ${ }^{3}$, Eric Márcio Balbino ${ }^{4}$, Erick Siqueira Araújo ${ }^{3}$}

\author{
1 Universidade Federal de Viçosa, Departamento de Biologia Animal, Av. P. H. Rolfs, s/n 36.570-000, Viçosa, MG, Brasil. \\ 2 Graduação em Zootecnia - UNESP - Botucatu, SP. \\ ${ }^{3}$ Graduando em Zootecnia - UFV - Viçosa, MG. \\ 4 Programa de Pós-Graduação em Zootecnia - UFV - Viçosa, MG.
}

\begin{abstract}
Dietary protein and energy requirements of juvenile freshwater angelfish (Pterophyllum scalare) were evaluated. A $3 \times 2$ factorial design was used, with three dietary crude protein levels being tested (26, 30, and 34\% of CP) combined with two digestible energy levels (3,100 and 3,300 kcal DE/kg of diet) in three replicates. Juveniles averaging $2.33 \pm 0.26$ g were reared in a $25 \mathrm{~L}$-aquarium with controlled temperature $\left(26 \pm 1^{\circ} \mathrm{C}\right)$, biological filter and stocking density of six fish/aquarium. Fish were fed ad libitum at 09:00 a.m., 2:00 p.m. and 4:30 p.m. The following performance parameters were evaluated: final weight, final length, weight gain, feed intake, feed conversion ratio, specific growth rate, protein efficiency ratio and condition factor. Fish fed diets with $26 \%$ CP showed greater protein efficiency values when compared to those fed diets with $34 \%$ CP. Diets with $26 \%$ of CP and $3100 \mathrm{kcal} \mathrm{DE} / \mathrm{kg}$ could meet the nutritional requirements of juvenile freshwater angelfish.
\end{abstract}

Key Words: growth, ornamental fish, productive performance, protein/energy ratio, Pterophyllum scalare

\section{Exigências nutricionais de proteína e energia em juvenis de acará-bandeira}

RESUMO - Avaliaram-se as exigências nutricionais de proteína e energia em juvenis de acará-bandeira (Pterophyllum scalare). Utilizou-se delineamento inteiramente casualizado, em esquema fatorial $3 \times 2$, com três níveis de proteína bruta (26, 30 e 34\%), dois de energia digestível (3.100 e $3.300 \mathrm{kcal} / \mathrm{kg}$ de ração) e três repetições. Juvenis com peso médio de $2,33 \pm 0,26$ g foram distribuídos em aquários contendo 25 litros de água, temperatura controlada $\left(26 \pm 1^{\circ} \mathrm{C}\right)$ e filtro biológico, na densidade de estocagem de seis animais por aquário. Os peixes foram alimentados à vontade às 9,14 e $16 \mathrm{~h} 30$. $\mathrm{Na}$ análise do desempenho produtivo, foram avaliados o peso final, o comprimento final, o ganho de peso, o consumo de ração, a conversão alimentar, a taxa de crescimento específico, a taxa de eficiência protéica e o fator de condição. As dietas contendo 26\% PB proporcionaram maiores valores para taxa de eficiência protéica apenas em relação às dietas contendo 34\% PB. As exigências nutricionais de proteína e energia em juvenis de acará-bandeira podem ser atendidas com dietas contendo $26 \%$ PB e $3.100 \mathrm{kcal} \mathrm{ED/kg}$.

Palavras-chave: crescimento, desempenho produtivo, peixes ornamentais, Pterophyllum scalare, relação proteína/ energia

\section{Introduction}

Ornamental fish culture is a rapidly expanding segment of aquaculture and is one of the most profitable sectors of Brazilian fish culture (Lima et al., 2001). However, little attention is paid to ornamental species rearing in South America probably because the export trade is based on collection of fish from the wild (Conroy, 1975).

Freshwater angelfish (Pterophyllum scalare) is one of the most popular and accessible species from the Cichlidae family, mainly because of its beauty, various colors and fin shapes (Swann, 1999).
Knowing the nutritional requirements of different fish species is one of the first steps to create new technologies for fish production. Nevertheless, there are few data and studies on the nutritional requirements of ornamental fish species (Blom et al., 2000; Sales \& Janssens, 2003), and they are not conclusive enough to formulate proper balanced diets (Boonyaratpalin \& Lovell, 1977).

Proteins are the main organic constituent of fish tissues. Thus, these animals need to ingest protein to obtain amino acids to synthesize new proteins (growth) or replace existing ones (maintenance). The optimum protein levels in the diet for fish, as for other animals, 
are influenced by the dietary protein and energy balance, amino acid composition, protein digestibility and availability of non-protein energy sources (carbohydrates and lipids) in the diet (Wilson, 2002).

It has been demonstrated that a diet with energy deficiency or excess can reduce the fish growth rate. An energy-deficient diet would result in the use of protein as energy source for maintenance in detriment to animal growth. However, a diet with energy excess, compared to protein would lead to less food intake and consequently less protein and other nutrient ingestion, essential for maximum animal growth (NRC, 1993).

Thus, the aim in the present study was to assess the nutritional protein and energy requirements for juvenile freshwater angelfish.

\section{Material and Methods}

The present study was carried out in the Fish Nutrition Laboratory in the Pisciculture Sector of the Department of Animal Biology at the Federal University of Viçosa, Brazil.
A complete randomized design was used in a $3 \times 2$ factorial experiment, with diets containing three crude protein levels (26, 30 and 34\%) and two digestible energy levels (3,100 and 3,300 kcal/kg of diet) in three replications. Diets (Table 1) were formulated based on the chemical composition of the feedstuffs (Rostagno et al., 2005) and nutrient digestibility for Nile tilapia (Miranda et al., 2000, Pezzato et al., 2002).

Juvenile freshwater angelfish ( $P$. scalare) were stoked at six fish per aquarium $(2.33 \pm 0.26 \mathrm{~g})$ into 25 -L polyethylene aquaria, fitted with biological filter, aeration and controlled temperature $\left(26 \pm 1^{\circ} \mathrm{C}\right)$. The aquaria were periodically siphoned for feces removal.

For diet preparation, ingredients were ground into fine powder, mixed by hand, moistened with water $\left(50 \pm 5^{\circ} \mathrm{C}\right.$ ), pelleted and oven-dried for 24 hours at $55 \pm 5^{\circ} \mathrm{C}$. After drying, diets were broken up and sieved to obtain proper pellet size $(0.75-1.30 \mathrm{~mm})$. Fish were fed $a d$ libitum at 9:00 a.m., 2:00 p.m. and 4:30 p.m. for a period of 50 days.

At the end of the experiment, the following productive performance parameters were assessed: final weight (FW),

Table 1 - Feed ingredients and calculated proximate composition of the experimental diets

\begin{tabular}{|c|c|c|c|c|c|c|}
\hline \multirow[b]{2}{*}{ Ingredient } & \multicolumn{6}{|c|}{ Experimental diet } \\
\hline & $26 / 3900$ & $26 / 4100$ & $30 / 3900$ & $30 / 4100$ & $34 / 3900$ & $34 / 4100$ \\
\hline Meat meal & 13.80 & 13.80 & 13.80 & 13.80 & 13.80 & 13.80 \\
\hline Soybean meal & 30.50 & 31.50 & 42.00 & 43.00 & 52.70 & 54.40 \\
\hline Wheat meal & 20.00 & 20.00 & 16.00 & 15.00 & 16.00 & 11.00 \\
\hline Corn meal & 34.17 & 29.18 & 26.99 & 23.40 & 16.35 & 16.24 \\
\hline Soybean oil & - & 4.00 & - & 3.60 & - & 3.40 \\
\hline DL - Methionine & 0.35 & 0.36 & 0.34 & 0.34 & 0.32 & 0.33 \\
\hline L-Lysine & 0.35 & 0.33 & 0.04 & 0.03 & - & - \\
\hline Vitamin and mineral premix ${ }^{1}$ & 0.50 & 0.50 & 0.50 & 0.50 & 0.50 & 0.50 \\
\hline Salt $(\mathrm{NaCl})$ & 0.25 & 0.25 & 0.25 & 0.25 & 0.25 & 0.25 \\
\hline Vitamin C & 0.06 & 0.06 & 0.06 & 0.06 & 0.06 & 0.06 \\
\hline \multirow[t]{2}{*}{$\mathrm{BHT}^{2}$} & 0.02 & 0.02 & 0.02 & 0.02 & 0.02 & 0.02 \\
\hline & \multicolumn{6}{|c|}{ Computed proximate composition } \\
\hline Gross energy (kcal kg-1) & 3910.82 & 4136.67 & 3925.26 & 4128.48 & 3941.69 & 4134.60 \\
\hline Digestible energy $\left(\mathrm{kcal} \mathrm{kg}^{-1}\right)^{3}$ & 3119.36 & 3328.53 & 3108.59 & 3298.52 & 3083.61 & 3268.15 \\
\hline Crude protein (\%) & 26.09 & 26.12 & 30.12 & 30.11 & 34.09 & 34.09 \\
\hline Digestible protein $(\%)^{3}$ & 22.74 & 22.77 & 26.42 & 26.42 & 30.06 & 30.07 \\
\hline CP/GE (mg protein kcal-1) & 66.73 & 63.09 & 76.64 & 72.91 & 86.52 & 82.54 \\
\hline Crude fiber (\%) & 4.44 & 4.40 & 4.62 & 4.52 & 5.04 & 4.69 \\
\hline Ether Extract (\%) & 3.91 & 7.71 & 3.68 & 7.10 & 3.46 & 6.68 \\
\hline Calcium (\%) & 2.11 & 2.11 & 2.14 & 2.14 & 2.17 & 2.17 \\
\hline Available phosphorus $(\%)^{4}$ & 0.96 & 0.96 & 0.95 & 0.95 & 0.96 & 0.94 \\
\hline Methionine (\%) & 0.60 & 0.60 & 0.60 & 0.60 & 0.60 & 0.61 \\
\hline Lysine (\%) & 1.43 & 1.43 & 1.43 & 1.43 & 1.63 & 1.65 \\
\hline
\end{tabular}


final length (FL), weight gain (WG), feed intake (FI), feed conversion ratio (FCR), specific growth rate (SGR), protein efficiency ratio (PER) and condition factor (K). The productive performance parameters were compared among treatments by analysis of variance, and when the F test was significant, Tukey test at $5 \%$ probability was used.

\section{Results and Discussion}

No significant differences were observed for the productive performance parameters among protein and energy levels, except for the protein efficiency ratio (Table 2). Diets containing 26\% CP showed similar values for PER compared to diets with $30 \% \mathrm{CP}$, and higher values when compared to diets containing $34 \% \mathrm{CP}$. Similar values for protein efficiency ratio were obtained by Ribeiro et al. (2007) for freshwater angelfish fry fed diets with 26, 28, 30 and 32\% CP, but no differences were detected among diets. Chong et al. (2000) assessed protein requirements for discus (Symphysodon spp.) and obtained lower values than those detected in the present study for PER (0.57 to 1.02), using diets containing 35, 40, 45, 50 and 55\% CP. Higher values for PER were observed here for freshwater angelfish, when compared to other species, which may indicate that this species can be fed diets with low protein levels.

The improve in efficiency protein utilization could be also associated with decreases in the amounts of nitrogen wasted by fish into the water (Ruohonen et al., 1999), which are especially important for ornamental fish, which are frequently raised in small tanks.

The weight gain values obtained in the present study were similar to the mean value (1.31 g) observed by Rodrigues \& Fernandes (2006) for fry from the same species. Luna-Figueroa (2003) reported weight gains of 0.63, 0.68 and $0.78 \mathrm{~g}$ for freshwater angelfish fry fed commercial diets with 27, 43 and 45\% CP, respectively. This variation in weight gain for the same species may be related to factors including quality of the protein used (amino acid composition and digestibility), feeding frequency, amount of diet supplied and the animal development stage.

The low values observed for the specific growth rate (SGR) of fish from the present study can be explained by the fish development phase, since the SGR decreases as fish increases in size (Sunde et al., 1998). Higher SGR values were reported by Luna-Figueroa (2003), Rodrigues \& Fernandes (2006) and Zuanon et al. (2006) (4.34, 2.04 and $2.47 \%$ /day, respectively), for fish of the same species, but smaller sizes than the fish from the present study.

The feed conversion ratio was not affected by dietary protein and energy content in juvenile angelfish. Probably, the diet protein and energy levels had not intervened with feed intake regulation for this fish species, and consequently they had not affected the feed conversion ratio. Possibly, the variation range in the dietary energy content, in the tested diets was not enough

Table 2 - Performance of freshwater angelfish fed diets with three crude protein levels (26, 30 and 34\%) and two digestible energy levels (3,100 and 3,300 kcal/kg) over 50 days $^{1}$

\begin{tabular}{|c|c|c|c|c|c|c|c|c|c|}
\hline $\begin{array}{l}\text { Crude protein } \\
\text { levels (\%) }\end{array}$ & $\begin{array}{l}\text { Digestible energy } \\
\text { levels (kcal/kg) }\end{array}$ & $\mathrm{FW}^{2}(\mathrm{~g})$ & $\mathrm{FL}^{3}(\mathrm{~mm})$ & $W^{4}(g)$ & $\mathrm{FI}^{5}(\mathrm{~g})$ & $\mathrm{FCR}^{6}$ & $\mathrm{SGR}^{7}$ (\%/day) & $\mathrm{PER}^{8}$ & $\mathrm{~K}^{9}$ \\
\hline 26 & $\begin{array}{l}3,100 \\
3,300\end{array}$ & $\begin{array}{l}3.70 \\
3.73\end{array}$ & $\begin{array}{l}41.34 \\
42.06\end{array}$ & $\begin{array}{l}1.37 \\
1.64\end{array}$ & $\begin{array}{l}3.07 \\
3.08\end{array}$ & $\begin{array}{l}2.25 \\
2.24\end{array}$ & $\begin{array}{l}0.93 \\
0.93\end{array}$ & $\begin{array}{l}1.71 \\
2.06\end{array}$ & $\begin{array}{l}1.52 \\
1.57\end{array}$ \\
\hline 30 & $\begin{array}{l}3,100 \\
3,300\end{array}$ & $\begin{array}{l}3.86 \\
3.96\end{array}$ & $\begin{array}{l}41.82 \\
42.20\end{array}$ & $\begin{array}{l}1.53 \\
1.62\end{array}$ & $\begin{array}{l}3.21 \\
2.89\end{array}$ & $\begin{array}{l}2.14 \\
1.81\end{array}$ & $\begin{array}{l}1.02 \\
1.05\end{array}$ & $\begin{array}{l}1.58 \\
1.86\end{array}$ & $\begin{array}{l}1.56 \\
1.56\end{array}$ \\
\hline 34 & $\begin{array}{l}3,100 \\
3,300\end{array}$ & $\begin{array}{l}3.85 \\
3.79\end{array}$ & $\begin{array}{l}42.38 \\
41.64\end{array}$ & $\begin{array}{l}1.53 \\
1.45\end{array}$ & $\begin{array}{l}2.91 \\
2.82\end{array}$ & $\begin{array}{l}1.92 \\
1.98\end{array}$ & $\begin{array}{l}1.03 \\
0.96\end{array}$ & $\begin{array}{l}1.55 \\
1.51\end{array}$ & $\begin{array}{l}1.50 \\
1.54\end{array}$ \\
\hline CV (\%) & & 10.90 & 3,69 & 15.05 & 8.08 & 14.76 & 19.20 & 11.57 & 3.22 \\
\hline $\begin{array}{l}\text { Protein level effect } \\
26 \\
30 \\
34\end{array}$ & & $\begin{array}{l}\text { n.s. } \\
3.71 \\
3.91 \\
3.82\end{array}$ & $\begin{array}{l}\text { n.s. } \\
41.70 \\
42.01 \\
42.01\end{array}$ & $\begin{array}{l}\text { n.s. } \\
1.51 \\
1.57 \\
1.49\end{array}$ & $\begin{array}{l}\text { n.s. } \\
3.08 \\
3.05 \\
2.86\end{array}$ & $\begin{array}{l}\text { n.s. } \\
2.24 \\
1.98 \\
1.95\end{array}$ & $\begin{array}{l}\text { n.s. } \\
0.93 \\
1.04 \\
1.00\end{array}$ & $\begin{array}{c}0.05 \\
1.88 \mathrm{a} \\
1.72 \mathrm{ab} \\
1.53 \mathrm{~b}\end{array}$ & $\begin{array}{l}\text { n.s. } \\
1.55 \\
1.56 \\
1.52\end{array}$ \\
\hline
\end{tabular}

\footnotetext{
${ }^{1}$ Means in the same column followed by different letters are significantly different, ${ }^{2}$ Final weight, ${ }^{3}$ Final length, ${ }^{4}$ Weight gain, ${ }^{5}$ Feed intake, ${ }^{6}$ Feed conversion ratio,

${ }^{7}$ Specific growth rate, ${ }^{8}$ Protein efficiency ratio, ${ }^{9}$ Condition factor.
} 
to influence the feed intake, as reported by Meyer and Fracalossi (2004) in Rhamdia quelen fingerlings.

In the present study, no protein sparring effect was observed by energy supplementation in the diets for juvenile freshwater angelfish. The absence of protein sparring effect might have occurred due to the small difference (200 kcal) in the energy levels among the experimental diets. Similar results were obtained by Arzel et al. (1998) for triploid brown trout fry (Salmo trutta), by Ali \& Jauncey (2005) for African catfish (Clarias gariepinus) and by Peres and Oliva-Teles (1999) for juvenile European sea bass (Dicentrarchus labrax). However, several authors have reported the protein sparring effect in response of an increase in energetic content in the diet for several fish species (Shiau \& Lan, 1996; McGoogan \& Gatlin III, 2000; Ai et al., 2004; Meyer \& Fracalossi, 2004; Kim \& Lee, 2005).

The conflicting results on the protein sparring effect by energetic supplementation of diet reported in literature may be related to the protein and energy levels assessed (Mercer, 1982), digestibility and composition of the ingredients used (Ai et al., 2004), and fish species. The fish protein requirement determination has been influenced by the feed intake ratio of Sciaenops ocellatus (McGoogan and Gatlin III, 1998) and S. truta fry (Arzel et al., 1998), and can also affect the protein sparring effect.

Juvenile freshwater angelfish fed diet with 26\% CP, $3100 \mathrm{kcal} \mathrm{DE} / \mathrm{kg}$ with protein/energy ratio of $83.87 \mathrm{mg}$ protein/kcal presented growth equivalent to those fed diets with higher protein and energy contents, with protein/energy ratios ranging from 72.91 to $86.52 \mathrm{mg}$ of protein $/ \mathrm{kcal}^{-1}$. Ribeiro et al. (2007) using isoenergetic diets (3338.84 kcal DE/kg) containing 26, 28, 30 and 32\% CP concluded that the requirements for freshwater angelfish fry could be met with diets containing 32\% CP with $95.84 \mathrm{mg}$ of protein $/ \mathrm{kcal}^{-1}$. The low protein requirement by juveniles obtained in present study, compared to that of the fry from the same species, might be supported by the fact that the protein requirement decreases with fish growth (Dabrowski, 1986).

Freshwater angelfish presents low protein requirement and efficient use of the diet protein, indicating that low-cost complete diets can be elaborated and used, thus decreasing the feeding costs with this fish species production.

\section{Conclusions}

Diets with $26 \%$ of crude protein and 3100 of digestible energy/kg can meet the nutritional protein and energy requirements for juvenile freshwater angelfish.

\section{Acknowledgments}

The authors are thankful to the Union of Ornamental Fish Producers (UNIPEIXE) of Muriaé, MG - Brazil, who by mediation of the animal scientist Veronica Cruz, donated the fish used in this study. The authors would also like to thank Dra Mariella Bontempo Duca de Freitas for the assistance with text revision.

\section{Literature Cited}

AI, Q.; MAI, K.; LI, H. et al. Effects of dietary protein to energy ratios on growth and body composition of juvenile Japanese seabass, Lateolabrax japonicus. Aquaculture, v.230, p.507-516, 2004

ALI, M.Z.; JAUNCEY, K. Approaches to optimizing dietary protein to enery ratio for African catfish Clarias gariepinus (Burchell, 1822). Aquaculture Nutrition, v.11, p.95-101, 2005.

ARZEL, J.; METAILLER, R.; LE GALL, P. et al. Relationship between ration size and dietary protein level varying at the expense of carbohydrate and lipid in triploid brown trout fry, Salmo trutta. Aquaculture, v.162, p.259-268, 1998.

BLOM, J.H.; DABROWSKI, K.; EBELING, J. Vitamin C requirements of the angelfish Pterophyllum scalare. Journal of World Aquaculture Society, v.31, p.115-118, 2000.

BOONYARATPALIN, M.; LOVELL, R.T. Diet preparation for aquarium fishes. Aquaculture, v.12, p.53-62, 1977.

CHONG, A.S.C.; HASHIM, R; ALI, A.B. Dietary protein requirements for discus (Symphysodon spp.). Aquaculture Nutrition, v.6, p.275-278, 2000.

CONROY, D.A. An evaluation of the present state of world trade in ornamental fish. Rome: FAO, 1975. 128p (Fisheries Technical Paper, 146).

DABROWSKI, K.R. Ontogenetical aspects of nutritional requirements in fish. Comparative Biochemistry and Physiology, v.85A, n.4, p.639-655, 1986.

KIM, L.O.; LEE, S. Effect of dietary protein and lipid levels on growth and body composition of bagrid catfish, Pseudobagrus fulvidraco. Aquaculture, v.243, p.323-329, 2005.

LIMA, A.O.; BERNARDINO, G.; PROENÇA, C.E.M. Agronegócio de peixes ornamentais no Brasil e no mundo. Panorama da Aqüicultura, v.11, n.65, p.14-24, 2001.

LUNA-FIGUEROA, J. Pterophyllum scalare (Pisces: Cichidae) Influencia de alimento vivo en la producción y el crescimiento. In: CONGRESSO IBEROAMERICANO VIRTUAL DE ACUICUlTURA, 2., 2003, Madri. Anais eletrônicos... Disponível em: <http://www.civa2003.org/> Acesso em: 12/8/2005.

MCGOOGAN, B.B.; GATLIN III, D.M. Dietary manipulation affecting growth and nitrogenous waste production of red drum, Sciaenops ocellatus: II. Effect of energy levels and nutrient density at various feeding rates. Aquaculture, v.182, p.271-285, 2000 .

MCGOOGAN, B.B.; GATLIN III, D.M. Metabolic requirements of red drum, Sciaenops ocellatus, for protein and energy based on weight gain and body composition. Journal of Nutrition, v.128, p.123-129, 1998.

MERCER, L.P. The quantitative nutrient-response relationship Journal of Nutrition, v.112, p.560-566, 1982

MEYER, G.; FRACALOSSI, D.M. Proteín requirement of jundia figerlings, Rhandia quelen, at two dietary energy concentrations. Aquaculture, v.240, p.331-343, 2004.

MIRANDA, E.C.; PEZZATO, A.C.; PEZZATO, L.E. et al. Disponibilidade aparente de fósforo em ingredientes pela tilápia do Nilo (Oreochromis niloticus). Acta Scientiarum, v.22, n.3, p.669-675, 2000 . 
NATIONAL RESEARCH COUNCIL - NRC. Nutrient requirements of fish. Washington, D.C.: National Academy Press, 1993. $114 \mathrm{p}$.

PERES, H.; OLIVA-TELES, A. Effect of dietary lipid level on growth performance and feed utilization by European sea bass juveniles (Dicentrarchus labrax). Aquaculture, v.179, p.325-334, 1999.

PEZZATO, L.E.; MIRANDA, E.C.M.; BARROS, M.M. et al. Digestibilidade aparente de ingredientes pela tilápia do Nilo (Oreochromis niloticus). Revista Brasileira de Zootecnia, v.31, n.4, p.1595-1604, 2002.

RIBEIRO, F.A.S.; RODRIGUES, L.A.; FERNANDES, J.B.K. Desempenho de juvenis de acará-bandeira (Pterophyllum scalare) com diferentes níveis de proteína bruta na dieta. Boletim do Instituto de Pesca, v.33, n.2, p.195-203, 2007.

RODRIGUES, L.A.; FERNANDES, J.B.K. Influência do processamento da dieta no desempenho produtivo do acará bandeira (Pterophyllum scalare). Acta Scientiarum. Animal Science, v.28, n.1, p.113-119, 2006.

ROSTAGNO, H.S.; ALBINO, L.F.T.; DONZELE, J.L. et al. Composição de alimentos e exigências nutricionais de aves e suínos: tabelas brasileiras para aves e suínos. 2.ed. Viçosa, MG: Editora UFV, 2005. 186p.
RUOHONEN, K.; VIELMA, J.; GROVE, D.J. Low-protein supplement increases protein retention and reduces the amounts of nitrogen and phosphorus wasted by rainbow trout fed on lowfat herring. Aquaculture Nutrition, v.5, p.83-91, 1999.

SALES, J.; JANSSENS, G.P.J. Nutrient requirements of ornamental fish. Aquatic Living Resources, v.16, n.6, p.533-540, 2003.

SHIAU, S.Y.; LAN, C.W. Optimum dietary protein level and protein to energy ratio for growth of grouper (Epinephelus malabaricus). Aquaculture, v.145, p.259-266, 1996.

SUNDE, L.M.; IMSLAND, A.K.; FOLKVORD, A. et al. Effects of size grading on growth and survival of juvenile turbot at two temperatures. Aquaculture International, v.6, p.19-32, 1998.

SWANN, L.D. Reproduction of angelfish (Pterphyllum scalare) Illinois: Aquaculture Extension, Indiana Sea Grant Program, Purdue University, 1999. 2p.

WILSON, R.P. Amino acids and proteins. In: HALVER, J.E.; HARDY, R.W. (Eds.) Fish nutrition. 3.ed. Orlando: Academic Press, 2002. p.144-179.

ZUANON, J.A.S.; SALARO, A.L.; BALBINO, E.M. et al. Níveis de proteína bruta em dietas para acará-bandeira. Revista Brasileira de Zootecnia, v.35, n.5, p.1893-1896, 2006. 